\title{
Socio-demographic Characteristics of Women with Reproductive Tract Infection Attending a Military Hospital
}

\author{
Hossain ABMB ${ }^{1}$, Rashid-Un-Nabi QMㄹㄹ , Alam Mj ${ }^{3}$, Islam SS4, Ameen SME ${ }^{5}$
}

DOI: https:/ / doi.org/ 10.3329/ jafmc.v15i2.50843

\begin{abstract}
Introduction: Reproductive tract infections (RTIS) are being increasingly recognized as a serious global health problem with impact on individual women and men, their families and communities. RTIs are a group of disease that cause infection of the genital tract and include both those that are sexually transmitted and those that are not. RTIs are a significant cause of morbidity and mortality in both men and women, especially in women of reproductive age.
\end{abstract}

Objectives: To determine the socio-demographic characteristics among women with RTIs attending at gynecology outpatient department, $\mathrm{CMH}$, Dhaka.

Materials and Methods: This descriptive cross-sectional study was carried out with a view to find out the socio-demographic characteristics of women with RTIs and their common clinical presentations. The study was conducted among women of reproductive age group of Bangladesh Armed Forces attending at Gynecology OPD, CMH Dhaka, for the period of 1st march to $30^{\text {th }}$ June 2011. A total of 128 women (114 married and 14 were unmarried) were interviewed with the help of structured question and checklist. Data was collected through clinical diagnostic approach made by gynecologists.

Results: It was found that highest percentage of respondents (32.8\%) were in the age group of 30-34 years, mean age at marriage was 17.79 years. The highest percentage of respondents (46.5\%) was married at the age range of 16-18 years. Among the respondents, $89.1 \%$ were married and $10.9 \%$ were unmarried. The women with higher education level had lower occurrence of RTIs than women with lower education. In relation to status of spouse of married women, RTIs were significantly more among the wife of other ranks. Practice of personal hygiene during menstruation showed safe positive impact on RTIs. It was found that 50\% respondents were presenting with vaginal discharge (Leucorrhoea). Most of the causes were vaginitis (38.3\%).

Conclusion: Study findings indicate that high prevalence of RTIS among women is due to the influence of less educational status, low income and also husband's educational background and employment status.

Key-words: Reproductive tract infection, Vaginitis, Pelvic inflammatory disease, Vaginal discharge.

\section{Introduction}

Reproductive tract infections (RTIS) are being increasingly recognized as a serious global health problem with impact on individual women and men, their families and communities. They can have severe consequences, including infertility, ectopic pregnancy, chronic pelvic pain, miscarriage and increased risk of HIV infection. RTIs are a significant cause of morbidity and mortality in both men and women, especially in women of reproductive age. The burden of RTIs is not shared equally around the world. RTIs are a group of disease that cause infection of the genital tract and include both those that are sexually transmitted and those that are not. In Bangladesh high percentage of (about 19000) women died annually due to pregnancy related causes $11 \%$ associated with infection and $21 \%$ with abortion. Globally, it is estimated that as many as 333 million new cases of curable sexually transmitted infection (STIS) other than HIVIAIDs occur each year1-3.

STIs patients are more likely to become infected with HIV, $75 \%$ when exposed to the virus and are more likely to transmit HIV when infected with virus ${ }^{2}$. Without treatment, $55-85 \%$ of women with pelvic inflammatory diseases (PIDs) may become infertile. PIDs increase the risk of ectopic pregnancy by 7-10 folds ${ }^{4}$. There are $10-30 \%$ of untreated men who had Gonorrhoea develop epididymitis and $20-40 \%$ of the epididymitis cases become infertile 5 . The World Health Organization (WHO) estimate show that in 1995, 150 million new cases of STIs occurred in South East Asia and 65 million in the Sub-Saharan Africa². That is why WHO has its major focus on STIs in the South East Asia and Sub-Saharan Africa. One study estimated that in 1990, the total direct and indirect costs of PIDs in the United States were about US \$ 3.5 billion2,4,5.

In Bangladesh, there is no national prevalence data on RTIS/STIS. There are three reasons to emphasize RTIs services in Bangladesh today. The limited number of prevalence studies point to an alarmingly high number of women with confirmed infections. Awareness regarding RTIs is low. About half of the RTIs cases did not think about the symptoms or ignore it as a disease. Globally as estimated by WHO, reproductive ill health accounts for $36.6 \%$ of the total disease burden in, women 4 . Reproductive health is a crucial part of general health and is central to development. It affects everybody and involves intimate and highly valued aspect6,7. Evidence shows that RTIS/STIs is quiet prevalent in Bangladesh. To date, only a few studies have been carried out to determine the prevalence of RTIS/STDs. To determine the socio-demographic characteristics among women with RTIs attending at gynecology outpatient department, $\mathrm{CMH}$, Dhaka this study was conducted.

\section{Materials and Methods}

This descriptive cross-sectional study was carried out with a view to find out the sociodemographic characteristics of women with RTIs and their common clinical presentations. The study was conducted among women of reproductive age group of Bangladesh Armed 
Forces attending at at Gynecology OPD, CMH Dhaka, for the period of $1^{\text {st }}$ march to $30^{\text {th }}$ June 2011 . A total of 128 women (114 married and 14 were unmarried) were interviewed with the help of structured questionnaire and checklist. Data was collected through clinical diagnostic approach made by gynaecologists. All collected data were checked verified thoroughly to reduce the inconsistency. The data were consolidated, processed, edited where necessary and was entered in computer and complied. Collected data were transferred to master tabulation sheet as per the specific objectives and key variables. It was analyzed by using statistical package for social science (SPSS) program.

\section{Results}

Total 128 patients' mean age was 29.05 years, ranging 15-49 years. It was found that majority of the respondents $(32.8 \%)$ in the range of 30-34 years followed by $28.1 \%$ from $25-29$ year, $13.3 \%$ from $35-40$ years and $11.7 \%$ in $20-24$ yrs. Mean age at marriage was $17.79 \pm 1.902$ years. It was observed that highest percentage $(46.5 \%)$ were married at the age range of $16-18$ years followed by $36.8 \%$ range $19-21$ years, $14.9 \%$ at the age below 15 years. It was found that majority $52(40.6 \%)$ had education up to SSC level, followed by $38(29.7 \%)$ below SSC, 31(24.3\%) HSC and only $7(5.5 \%)$ graduate. Mean monthly income was Taka 14433. Highest income (41.4\%) range from Taka 10000-15000 followed by $43(33.6 \%)$ in the range of Taka 15000-20000, 24(18.8\%) in the range of Taka 5000-10000 and $8(6.3 \%)$ in the range of Taka 20000 and above (Table-I).

It was found that among married women (114) 100 had history of pregnancy. The median number of pregnancy was 2 ranging from 1-6 times, $48.2 \%$ had history pregnancy $1-2$ times, $44.7 \%$ had history of pregnancy 3-3 times, $7 \%$ had history of 5 and above. Out of 114 respondents $95(83.3 \%)$ were without complications of abortion, 7(6.1\%) having fever, $10(8.8 \%)$ abdominal pain, 2(1.8\%) foul smelling PV discharge. Study revealed that $71.1 \%$ delivery conducted by the doctors and $26.3 \%$ were conducted by TBA. And few $2.6 \%$ conducted by others like relatives or untrained persons (Table-II). It was found that among the RTIs cases, highest percentage were in the age group $30-34$ year $(32.8 \%)$ most of them were vaginits $13.3 \%$. But no statistically significant age difference was found as $(p>0.05)$. Highest percentage of RTIs cases were secondary educated $40.6 \%$ and among them $15.6 \%$ having vaginitis (Table-III).
Table-l: Distribution of respondents by socio-demographic characteristics $(\mathrm{n}=128)$

\begin{tabular}{|c|c|c|c|}
\hline \multicolumn{2}{|c|}{ Characteristics } & Frequency & Percentage \\
\hline \multirow{4}{*}{$\begin{array}{l}\text { Age in } \\
\text { years }\end{array}$} & $15-24$ & 26 & 20.3 \\
\hline & $25-34$ & 78 & 60.9 \\
\hline & $35-44$ & 23 & 18.0 \\
\hline & $45-49$ & 1 & 0.8 \\
\hline \multirow{5}{*}{$\begin{array}{l}\text { Age at } \\
\text { marriage }\end{array}$} & $\leq 15$ & 17 & 14.9 \\
\hline & $16-18$ & 53 & 46.5 \\
\hline & $19-21$ & 42 & 36.8 \\
\hline & $\geq 22$ & 2 & 1.8 \\
\hline & Total & 114 & 100.0 \\
\hline \multirow{4}{*}{$\begin{array}{l}\text { Education } \\
\text { level }\end{array}$} & Below SSC & 38 & 29.7 \\
\hline & SSC & 52 & 40.6 \\
\hline & $\mathrm{HSC}$ & 31 & 24.2 \\
\hline & Graduation & 7 & 5.5 \\
\hline \multirow{4}{*}{$\begin{array}{l}\text { Monthly } \\
\text { family } \\
\text { income in } \\
\text { Taka }\end{array}$} & $5000-10000$ & 24 & 18.8 \\
\hline & $10000-15000$ & 53 & 41.4 \\
\hline & $15000-20000$ & 43 & 33.6 \\
\hline & $>20000$ & 8 & 6.2 \\
\hline
\end{tabular}

Table-II: Distribution of respondents by pregnancy, abortion and delivery related information $(n=114)$

\begin{tabular}{|c|c|c|c|}
\hline \multicolumn{2}{|c|}{ Characteristics } & Frequency & Percentage \\
\hline \multirow{3}{*}{$\begin{array}{l}\text { Number of } \\
\text { pregnancy }\end{array}$} & $\leq 2$ & 55 & 48.2 \\
\hline & $3-4$ & 51 & 44.7 \\
\hline & $\geq 5$ & 8 & 7.1 \\
\hline \multirow{4}{*}{$\begin{array}{l}\text { Complication } \\
\text { of abortion }\end{array}$} & Fever & 7 & 6.1 \\
\hline & $\begin{array}{l}\text { Pain } \\
\text { abdomen }\end{array}$ & 10 & 8.8 \\
\hline & $\begin{array}{l}\text { Foul } \\
\text { smelling } \\
\text { PV } \\
\text { discharge }\end{array}$ & 2 & 1.8 \\
\hline & Nil & 95 & 83.3 \\
\hline \multirow{3}{*}{$\begin{array}{l}\text { Delivery } \\
\text { attended by }\end{array}$} & Doctor & 81 & 71.1 \\
\hline & TBA & 30 & 26.3 \\
\hline & Others & 3 & 2.6 \\
\hline
\end{tabular}

Table-III: Relationship between age group and education status of respondents with diagnosis of RTIs ( $n=128)$

\begin{tabular}{|c|c|c|c|c|c|c|c|c|}
\hline \multirow{2}{*}{\multicolumn{2}{|c|}{ Characteristics }} & \multicolumn{5}{|c|}{ Diagnosis of RTIs } & \multirow[b]{2}{*}{ Total } & \multirow[b]{2}{*}{ Statistics } \\
\hline & & \multirow{2}{*}{$\begin{array}{c}\text { Vaginitis } \\
5(3.9)\end{array}$} & \multirow{2}{*}{$\begin{array}{c}\text { Cervicitis } \\
0\end{array}$} & \multirow{2}{*}{$\begin{array}{c}\text { PID } \\
2(1.6)\end{array}$} & \multirow{2}{*}{$\begin{array}{c}\begin{array}{c}\text { Vulvo- } \\
\text { vaginitis }\end{array} \\
3(2.3)\end{array}$} & \multirow{2}{*}{$\begin{array}{c}\text { Salphingitis } \\
1(0.8)\end{array}$} & & \\
\hline \multirow{8}{*}{$\begin{array}{l}\text { Age group } \\
\text { in Years }\end{array}$} & $15-19$ & & & & & & $11(8.6)$ & \multirow{8}{*}{$\begin{array}{l}X^{2}=17.62 \\
d f=24 \\
p>0.05\end{array}$} \\
\hline & $20-24$ & $7(5.5)$ & $3(2.3)$ & $3(2.3)$ & $2(1.6)$ & 0 & $15(11.7)$ & \\
\hline & $25-29$ & $13(10.2)$ & $10(7.8)$ & $6(4.7)$ & $5(3.9)$ & $2(1.6)$ & $36(28.1)$ & \\
\hline & $30-34$ & $17(13.3)$ & $6(4.7)$ & $7(5.5)$ & $10(7.8)$ & $2(1.6)$ & $42(32.8)$ & \\
\hline & $35-39$ & $6(4.7)$ & $2(1.6)$ & $2(1.6)$ & $6(4.7)$ & $1(0.8)$ & $17(13.3)$ & \\
\hline & $40-44$ & $1(0.8)$ & $1(0.8)$ & $2(1.6)$ & $1(0.8)$ & $1(0.8)$ & $6(4.7)$ & \\
\hline & $45-49$ & 0 & $1(0.8)$ & 0 & 0 & 0 & $1(0.8)$ & \\
\hline & Total & $49(38.3)$ & $23(18.0)$ & $22(17.2)$ & $27(21.1)$ & $7(5.5)$ & $128(100)$ & \\
\hline \multirow{5}{*}{$\begin{array}{l}\text { Educational } \\
\text { status }\end{array}$} & $<$ SSC & $11(8.6)$ & $9(7.0)$ & $7(5.5)$ & $9(7.0)$ & $2(1.6)$ & $38(29.7)$ & \multirow{5}{*}{$\begin{array}{l}x 2=9.77 \mathrm{df} \\
=12 \\
p>0.05\end{array}$} \\
\hline & SSC & $20(15.6)$ & $7(5.5)$ & $11(8.6)$ & $11(8.6)$ & $3(2.3)$ & $52(40.6)$ & \\
\hline & HSC & $16(12.5)$ & $4(3.1)$ & $4(3.1)$ & $5(3.9)$ & $2(1.6)$ & $31(24.2)$ & \\
\hline & Graduation & $2(1.6)$ & $3(2.3)$ & 0 & $2(1.6)$ & 0 & $7(5.5)$ & \\
\hline & Total & $49(38.3)$ & $23(18.0)$ & $22(17.2)$ & $27(21.1)$ & $7(5.5)$ & $128(100)$ & \\
\hline
\end{tabular}




\section{Discussion}

Reproductive tract infections account for a major burden of disease globally especially in the developing countries like Bangladesh. In Bangladesh reproductive health issue is surrounded by a "Culture of Silence". Women suffering from these problem, feel shy to seek medical care and afraid to discuss about it due to social stigma, cultural tradition and religious norms. In this study a total 128 women of reproductive age was interviewed. The mean age of the respondent was 29.05 yrs. Majority (32.8\%) were in the age group 30-34 years followed by $28.1 \%$ were in $25-29$ years. The result was similar with the study of Latifa 5 where mean age of the respondent were 31.4 years. Regarding level of education, among armed forces the female literacy rate is very high. But the picture of RTIs with education is different here highest percentage $(40.6 \%)$ of RTIs having SSC education followed by $29.7 \%$ having below SSC education and $24.2 \%$ having HSC education level. It was observed that among the respondent highest percentage $(41.4 \%)$ in the income group of Tk. 10000-15000. But the difference was not statistically significant $(p>0.05)$. It indicates the low socio-economic group is more victims of RTIs. Early marriage is common in Bangladesh adolescent girls. In this study mean age at marriage was 17.79 years and the highest (46.5\%) were married at the range of 16-18 years. A study by Chowdhury et al ${ }^{7}$ find out that mean age of marriage of the respondent was 15.5 years and age at first child birth was nearly 18 years. The early age of marriage and childbirth indirectly reflect early initiation of sexual activity.

In this study majority (71.1\%) respondents had history of delivery in hospital and rest $28.9 \%$ home delivery. Regarding mode of delivery majority $61.7 \%$ had normal delivery followed by $26.6 \%$ caesarean section. No statistically significant association was focused RTI and place of delivery. The similar studies, $8,9,10$ found RTI was more $60.8 \%$ who delivered at home which might be due to delivery at home was conducted by untrained dais. It was also found that RTI was higher $60.0 \%$ among the respondents having history of assisted delivery compared to normal delivery. It was found in the study; RTI is highest $(58.8 \%)$ in NCOs/ORs wives followed by $25.4 \%$ in civilian employee's wives and lowest in officer's wives. It is seen in the study that RTI gradually decrease from lower to higher social class. Similar result was found with the study of Latifa ${ }^{5}$, who found $54.1 \%$ of RTI cases were ORs wives. But the incidence is comparatively a bit less in civilian employee's wives probably due to lack of awareness they feel it, beside that they are residing outside the cantonment. Due to communication problem they are not interested to report here with this type of problem which is chronic but not fatal.

Regarding clinical diagnosis this study found highest 38.3\% having vaginitis among the respondents followed by $21.1 \%$ having valvovaginitis, $18 \%$ cervicitis and $17.2 \%$ having PID. Due to time and financial constrain maximum diagnosis was not supported by laboratory investigation. All these findings suggest that the proportion of RTIs and associated risk factors were prevailing among the study population, in spite of better socio-economic and medical facilities enjoyed by them.

\section{Conclusion}

Study findings indicate that high prevalence of RTIs among women is due to the influence of less educational status, low income and also husband's educational background and employment status. RTIs were more with large family size, repeated use of old cloth during menstruation and less frequency of changing pad. RTIs were found higher among those who were early married, repeated pregnancy and home delivery conducted by untrained Dais. This study is an attempt which revealed some information related to RTIS among the armed forces women. A large scale explorative study may be undertaken to find out the extent of problem and to guide appropriate preventive measures to be taken to consent RTIs. This requires immediate attention by the policymaker service provider, as well as the general population of the Armed Forces.

\section{References}

1. Reproductive Health Outlook (RHO). Reproductive Tract Infections. http://www.abode/Com/products/ acrobat/readstep.html. Viewed on 2nd January 2005.

2. Directorate General Health Services. Government of Bangladesh (GOB): Capacity Development through Training for the Reproductive Health programme, 3rd ed, Dhaka; June 2003:399-501.

3. Rob U. Integration of RT1 Care into Existing Family Planning services in Bangladesh, The possible and the practical. Social change 1996; 26(38(4):186-95.

4. World health Organization. Reproductive Health, A key to a brighter future. Biennial Report 1992:12-13.

5. Rahman L. Socio-demographic characteristics of Reproductive Tract Infection among women attending Gynaecolog OPD CMH Dhaka. Unpublished Dissertation of MPH (PHA) Course, NIPSOM; 2002.

6. Begum N. Reproductive Tract Infections. Among female workers of a selected garments factory. Unpublished Dissertation of MPH (MCH\&FP) course, NIPSOM 2001:1-30.

7. Chowdhury AH. Client satisfaction and provider's perception on syndromic management of Reproductive Tract Infections. Unpublished Dissertation of MPH (RCH) course, NIPSOM 2003:6-9.

8. World Health Organization. Women of South-East Asia. A Health profile. Regional Publication, 2000; 34:93

9. World Health Organizatio and World Bank. Special programme of research, development and research training in Human Reproduction 1994; 32:8.

10. Garge S, Sharma N, Bhalla P et al. Reproductive Morbidity in an Indian Urban Slum. New Delhi, India; 2002:68-9. 